
The Weinstock Lectures on The fthrals of $\mathbb{C r a d e}$

THE CONFLICT BETWEEN PRIVATE MONOPOLY AND GOOD CITIZENSHIP. By JOHN GRAHAM BroOKs.

COMMERCIALISM AND JOURNALISM. BY HAMILTON HOLT.

THE BUSINESS CAREER IN ITS PUBLIC Relations. By Albert Shaw. 


\section{THE CONFLICT BETWEEN PRIVATE MONOPOLY AND \\ GOOD CITIZENSHIP}





\title{
THE CONFLICT BETWEEN PRIVATE MONOPOLY AND GOOD CITIZENSHIP
}

\author{
BY

\section{JOHN GRAHAM BROOKS} \\ PRESIDENT OF THE NATIONAL CONSUMERS' LEAGUE \\ AUTHOR OF "THE SOCIAL UNREST," \\ " AS OTHERS SEE US," ETC.
}

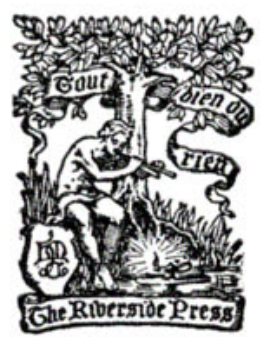

BOSTON AND NEW YORK HOUGHTON MIFFLIN COMPANY Cbe ribersioe pregig Cambrioge I909 
COPYRIGHT, 1909, BY THE REGENTS OF THI UNIVERSITY OF CALIFORNIA ALL RIGHTS RESERVED

Published December roog 


BARBARA WEINSTOCK
LECTURES ON THE MORALS
OF TRADE
This series will contain essays by
representative scholars and men of
affairs dealing with the various phases
of the moral law in its bearing on
business life under the new economic
order, first delivered at the University
of California on the Weinstock founda-
tion.


